\title{
Pepsi and Coca Cola in Delhi, India: availability, price and sales
}

\author{
Fiona C Taylor*, Ambika Satija, Swati Khurana, Gurpreet Singh and Shah Ebrahim \\ South Asia Network for Chronic Disease, C-1/52 First Floor, Safdarjung Development Area, \\ New Delhi 110016, India
}

Submitted 19 February 2010: Accepted 16 July 2010: First published online 6 0ctober 2010

\begin{abstract}
Objective: India is experiencing increased consumption of sugar-sweetened carbonated drinks, consumption that may be associated with increased risk of type 2 diabetes and obesity. The aim of the study was to determine the availability, price and quantity sold of 'Pepsi' and 'Coca Cola' in their 'regular' and 'diet' forms in Delhi and London.

Design: A questionnaire about the availability, price and quantity sold per day of both regular and diet Pepsi and Coca Cola was devised and piloted. Using this, a survey of food and drink outlets within a $100 \mathrm{~m}$ radius of randomly selected Metro stations was conducted in both cities.

Subjects: Store vendors, owners and staff of food and drink outlets.

Setting: Delhi, India; London, United Kingdom.

Results: In Delhi, of the outlets stocking regular Pepsi and Coca Cola, only 34\% sold diet versions and these were more readily available in the most affluent areas than in the poorest areas $(34 \% v .6 \%, Z=3 \cdot 67, P<0 \cdot 001)$. This social patterning was not observed in London. Little price differential between regular and diet versions of Pepsi and Coca Cola was observed in Delhi; however, profit margins were better for regular, relative to diet, Coca Cola. Sales of regular products were significantly greater than those of diet products $(P<0 \cdot 002)$.

Conclusions: Low availability of diet versions of Pepsi and Coca Cola in less affluent areas of Delhi is likely to exacerbate the obesity and diabetes trends. Price differentials to promote diet versions and other healthier or traditional low-energy drinks may be beneficial.
\end{abstract}

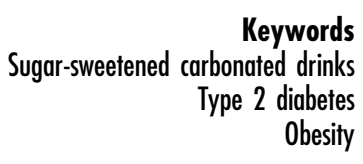

The nutrition transition occurring in the developing world, of which increased consumption of carbonated drinks is a part, results in the rapid adoption of energydense diets at low cost replacing energy-efficient diets at high costs ${ }^{(1-3)}$. Further evidence, although limited to developed countries, suggests that poorer areas provide fewer healthy food options and more energy-dense foods than do more affluent areas ${ }^{(4)}$. Evidence on consumption rates of soft drinks and processed foods by the Indian population is sparse ${ }^{(5)}$. Obesity and type 2 diabetes are already becoming major health problems in India ${ }^{(6)}$, and the health implications of further unchecked growth in the consumption of sugar-sweetened soft drinks may aggravate the situation further.

Systematic review evidence suggests that greater consumption of sugar-sweetened soft drinks is associated with weight gain in adults and children and increase in the risk of type 2 diabetes in young-to-middle-aged women $^{(7-9)}$. No such associations have been found with the consumption of diet drinks ${ }^{(10)}$. The age-adjusted relative risk for type 2 diabetes among women consuming one or more sugar-sweetened drinks per day compared with those consuming less than one sugar-sweetened drink per month is $1 \cdot 98$ (95\% CI $1 \cdot 6,2 \cdot 4)^{(10)}$.

Sugar-sweetened soft drink consumption has become a controversial public health issue in France and England resulting in regulations banning their sale in schools ${ }^{(9)}$. This is in reaction to growing evidence of associations found between sugar-sweetened soft drink intake in children and increased energy consumption, lower milk consumption, higher intake of carbohydrates and lower intake of fruit and dietary fibre ${ }^{(9)}$.

Accurate and up-to-date statistics on soft drink consumption are not readily available. As soft drink consumption has levelled off in the USA and parts of Europe, less developed countries such as India now represent the largest growth markets for soft drink producers ${ }^{(11-13)}$. While Coca Cola alone had increased its sales in India by 10.4\% from 1998 to $2003^{(14)}$, Euromonitor estimated that the average annual growth rate of all soft drink sales in India was $12.6 \%$ and that for carbonated drinks 4.8\% annually between 1997 and $2007^{(15)}$.

As wider marketing of low-energy 'diet' versions of carbonated drinks may be a reasonable means of harm 
reduction in India, given the prevalence of high obesity and diabetes, we sought to determine the availability, price and quantity sold of two of the globally most popular soft drink products - 'Pepsi' and 'Coca Cola' - in their regular and 'diet' forms. We surveyed the food and drink outlets in Delhi, India and London, UK for comparative purposes. Our hypotheses were that diet Pepsi and Coca Cola were equally available and at the same price and sold in the same quantity as regular Pepsi and Coca Cola both in Delhi and London.

\section{Methods}

We devised and piloted a questionnaire about the availability, price and quantity sold per day of both regular and diet Pepsi and Coca Cola in Delhi (see Appendix). We included a section of open-ended questions for store vendors, café, pub and/or restaurant staff regarding the stocking and sales of regular and diet Pepsi and Coca Cola. Prices were ascertained by checking the price labels and/or menus. For comparison on availability and price, we conducted the same survey in London to represent a city in the developed world. We made a list of stations of the Delhi Metro and the London Underground systems. From these lists, we randomly selected a $10 \%$ sample of stations of the Delhi Metro and a 3\% sample (reflecting the larger network) from the London Underground system. Within a $100 \mathrm{~m}$ radius of the selected Metro/Underground station, all food and drink outlets that were open, including those within the stations, were visited. We excluded nonpermanent stalls that were selling only freshly squeezed juice or tea and convenience items that did not include drinks. The questionnaire was administered on the premises by interview of the store vendors or staff in drinking and/or eating establishments. Data collection was undertaken over two 1-week periods in March 2009.

To ascertain an area profile for the selected areas in Delhi, we obtained data from the Census of India 2001 ${ }^{(16)}$ on the total population, the proportion of people who were illiterate, the proportion of marginal (temporarily) unemployed and economically active people. For London, data from the Census 2001 provided online by the Office of National Statistics were used ${ }^{(17)}$. We collected data on the total population and the proportions of the following indicators of socio-economic status: living in social housing (KS18), economically active long-term unemployed (KS09A), no qualifications (KS13) and classified as being in professional groups A + B (UV50 - higher and intermediate managerial/administrative/professional persons).

Data were entered on an EXCEL spreadsheet and analysed using the Statistical Package for Social Sciences statistical software package version 10.0 (SPSS Inc., Chicago, IL, USA) ${ }^{(18)}$. Since the range of prices was not normally distributed across establishments where regular and/or diet
Pepsi or Coca Cola was available, we used median prices. We used Z-tests to compare differences between low and high socio-economic areas and $\chi^{2}$ test to assess whether the observed differences in availability, cost and sales of regular and diet Pepsi and Coca Cola in Delhi and in London were compatible with chance alone.

We contacted the sales executive of PepsiCo and Coca Cola in India and in the UK for the manufacturing prices of regular and diet Pepsi and Coca Cola, the prices at which these were sold directly to the retailer and the recommended maximum retail price (MRP). Prices were analysed in Indian rupees (INR; 72 INR to £1.00 sterling as quoted on 20 March 2009) ${ }^{(19)}$.

\section{Results}

\section{The pilot}

Since the Metro system was not in operation in South Delhi, Green Park, a location close to the base of the research team in South Delhi was chosen for piloting the methods. No alterations after the pilot were made to the study, and therefore we included the data derived from the pilot in the study results.

For Delhi, but not for the UK, we were able to ascertain the price manufacturers charged retailers as well as the MRP for all the products investigated other than the $330 \mathrm{ml}$ can of diet Coca Cola.

\section{Area profiles, food and drink outlets}

The ward-level population in Delhi ranged between 18709 and 100716 and was much higher than the London range of 7185-9224. In total, 185 outlets were visited: 124 in seven areas in East, West, South, North and Central Delhi and sixty-one outlets in three areas in East, Central and South London. The area profile statistics showed that Tilak Nagar and Green Park (Delhi) and St Paul's (London) were the most affluent areas and that Mansorovar Park, Uttam Nagar (Delhi) and Pimlico (London) were the least affluent areas.

\section{Availability}

In Delhi, the availability of regular and diet Pepsi was greater than that of regular or diet Coca Cola. The reverse was the case for London. No outlets sold only the diet versions of Pepsi or Coca Cola. Pepsi or Coca Cola was available in a variety of different outlets and there was little difference in the availability of these products between Delhi (92/124, 74\%) and London (49/61, 80\%) outlets (Table 1).

Of the outlets stocking regular Pepsi and Coca Cola in Delhi, only thirty-two of ninety-two (34\%) sold diet Pepsi or Coca Cola and these outlets were mostly in the affluent areas: seventeen of fifty-three (32\%, 95\% CI 21, 46) compared to much more limited availability in the poorer areas, two of thirty-one $(6 \%, 95 \%$ CI $-2,21 ; Z=3 \cdot 67$, 
$P<0 \cdot 001)$. In contrast, all the outlets in London stocking regular Pepsi or Coca Cola also stocked their diet counterparts (Table 1). In London, diet Pepsi and Coca Cola were as much available in the least affluent areas where sixteen of nineteen $(84 \%, 95 \%$ CI 62,95$)$ outlets stocked them compared to the most affluent areas, fifteen of twenty-one (71\%, 95\% CI 50, 86; $Z=1 \cdot 01, P=0 \cdot 18)$.

In Delhi, fifty-three of 124 shop vendors or staff in drinking and/or eating establishments answered our openended questions on stocking and sales of regular and diet Pepsi and Coca Cola. Of these, twenty-eight (52\%) said that there was little or no demand for diet Pepsi or Coca Cola, ten $(36 \%)$ that their customers preferred regular to diet products and one argued that diet products were only for

Table 1 Store availability of regular $v$. diet Pepsi and Coca Cola: Delhi and London

\begin{tabular}{|c|c|c|c|c|c|}
\hline & \multicolumn{2}{|c|}{ Regular } & \multicolumn{2}{|c|}{ Diet } & \multirow[b]{2}{*}{ Total surveyed } \\
\hline & $n$ & $\%$ & $n$ & $\%$ & \\
\hline \multicolumn{6}{|l|}{ Delhi } \\
\hline High SEA & 39 & 74 & 17 & 32 & 53 \\
\hline Intermediate SEA & 30 & 75 & 13 & 32 & 40 \\
\hline Low SEA & 23 & 74 & 2 & 6 & 31 \\
\hline Total & 92 & 74 & 32 & 26 & 124 \\
\hline \multicolumn{6}{|l|}{ London } \\
\hline High SEA & 15 & 71 & 15 & 71 & 21 \\
\hline Intermediate SEA & 18 & 86 & 18 & 86 & 21 \\
\hline Low SEA & 16 & 84 & 16 & 84 & 19 \\
\hline Total & 49 & 80 & 49 & 80 & 61 \\
\hline
\end{tabular}

SEA, socio-economic area.

Delhi: high SEA areas - Green Park and Tilak Nagar; intermediate - Netaj Subhash, Chawri Bazaar and Kirti Nagar; low - Mansorovar Park and Uttam Nagar.

London: high SEA area - St. Paul; intermediate - Warren Street; low - Pimlico. sick people. Another reason for not stocking diet Pepsi or Coca Cola was lack of availability from the wholesaler. In London, of the twenty-four out of sixty-one (39\%) shop vendors or staff in drinking and/or eating establishments who responded to this section of the questionnaire, three $(12.5 \%)$ stated that their customers preferred regular to diet products; however, store vendors noted that sales of flavoured water were fast outstripping carbonated drink sales.

\section{Price}

Different-sized containers of regular and diet Pepsi and Coca Cola were available in Delhi and London. For a fair comparison of prices between diet and regular versions, we compared same-sized containers, i.e. $330 \mathrm{ml}$ cans, 500 and $600 \mathrm{ml}$ bottles in Delhi; $330 \mathrm{ml}$ cans and $500 \mathrm{ml}$ bottles in London.

\section{Pepsi}

For Delhi, the price that the manufacturers charged retailers, the MRP and the median price derived from our data are shown in Table 2 . There were no price differentials between diet and regular Pepsi in all quantities sold other than a 1 INR higher price for $330 \mathrm{ml}$ cans, which was explained by two restaurants that charged more for diet than regular. All store vendors charged the same price for diet and regular Pepsi. There were no other differences between the MRP and the median price derived from our data. Retailers would make $10 \%$ profit selling a can of regular Pepsi compared to an $8 \%$ profit selling diet Pepsi and in all other quantities the profit margin was the same (Table 2). In London, the price for diet $333 \mathrm{ml}$ cans was almost double that of regular Pepsi.

Table 2 Regular and diet Pepsi and Coca Cola: prices that the manufacturers charged retailers, MRP and median price in INR $(72$ INR $=£ 1)$ in Delhi and London

\begin{tabular}{|c|c|c|c|c|}
\hline & Quantity (ml) & Manufacturing price (INR) & MRP & Median price (range) \\
\hline \multicolumn{5}{|l|}{ Delhi } \\
\hline \multirow[t]{3}{*}{ Regular Pepsi } & 330 & $22 \cdot 5$ & 25 & $25(15-50)$ \\
\hline & 500 & $18 \cdot 5$ & 20 & $20(20-22)$ \\
\hline & 600 & $18 \cdot 5$ & 20 & $20(20-20)$ \\
\hline \multirow[t]{3}{*}{ Diet Pepsi } & 330 & $22 \cdot 5$ & 25 & $26(25-50)$ \\
\hline & 500 & $18 \cdot 5$ & 20 & $20(20-25)$ \\
\hline & 600 & $18 \cdot 5$ & 20 & $20(20-22)$ \\
\hline \multirow[t]{3}{*}{ Regular Coca Cola } & 330 & $18 \cdot 0$ & 20 & $25(15-25)$ \\
\hline & 500 & $18 \cdot 5$ & 22 & $22(20-45)$ \\
\hline & 600 & $18 \cdot 5$ & 22 & $22(20-22)$ \\
\hline \multirow[t]{3}{*}{ Diet Coca Cola } & 330 & $22 \cdot 5$ & Not stated & $25(15-45)$ \\
\hline & 500 & $22 \cdot 0$ & 25 & $25(23-45)$ \\
\hline & 600 & $22 \cdot 0$ & 25 & $22 \cdot 5(22-25)$ \\
\hline \multicolumn{5}{|l|}{ London } \\
\hline \multirow[t]{2}{*}{ Regular Pepsi } & 330 & - & - & $40(36-108)$ \\
\hline & 500 & - & - & 79 (64-89) \\
\hline \multirow[t]{2}{*}{ Diet Pepsi } & 330 & - & - & $77 \cdot 5(47-108)$ \\
\hline & 500 & - & - & $82 \cdot 5(64-89)$ \\
\hline \multirow[t]{2}{*}{ Regular Coca Cola } & 330 & - & - & $54(35-180)$ \\
\hline & 500 & - & - & $83(68-104)$ \\
\hline \multirow[t]{2}{*}{ Diet Coca Cola } & 330 & - & - & $54(35-180)$ \\
\hline & 500 & - & - & $83(68-104)$ \\
\hline
\end{tabular}

MRP, maximum retail price; INR, Indian rupees. 
Table 3 Average daily sales of the different quantities of regular and diet Pepsi ${ }^{\star}$ in ninety-two Delhi and forty-nine London outlets

\begin{tabular}{lcccccccrrr}
\hline & \multicolumn{7}{c}{ Size of container (I) } & Totalt \\
\cline { 2 - 7 } & 0.2 & 0.25 & 0.3 & 0.33 & 0.45 & 0.5 & 0.6 & 2 & 2260 \\
\hline $\begin{array}{l}\text { Delhi } \\
\quad \text { Regular (I) }\end{array}$ & 155 & 185 & 784 & 43 & - & 89 & 735 & 272 & 90 \\
$\quad$ Diet (I) & NR & - & - & NR & - & 74 & 20.5 & - & 2 & 200 \\
$\begin{array}{l}\text { London } \\
\quad \text { Regular (I) }\end{array}$ & - & 10 & NR & 18 & - & 166 & - & NR & 90 \\
Diet (I) & - & 10 & - & 5 & 79 & - & - & \\
\hline
\end{tabular}

${ }^{\star}$ Total quantity in terms of total numbers of bottles and/or cans sold; NR indicates where no sales figures were provided. tTotal figures have been rounded off to the nearest 10 .

Table 4 Average daily sales of the different quantities of regular and diet Coca Cola* in ninety-two Delhi and forty-nine London outlets

\begin{tabular}{|c|c|c|c|c|c|c|c|c|c|c|c|}
\hline & \multicolumn{10}{|c|}{ Size of container (I) } & \multirow[b]{2}{*}{ Total } \\
\hline & 0.2 & $0 \cdot 25$ & $0 \cdot 3$ & 0.33 & 0.35 & $0 \cdot 4$ & 0.45 & 0.5 & $0 \cdot 6$ & 2 & \\
\hline \multicolumn{12}{|l|}{ Delhi } \\
\hline Regular (I) & 92 & 11 & 549 & 65 & 6 & 100 & - & 48 & 422 & 122 & 1420 \\
\hline Diet (I) & - & - & NR & 28 & - & NR & - & 48 & $52 \cdot 5$ & - & 80 \\
\hline \multicolumn{12}{|l|}{ London } \\
\hline Regular (I) & 0.5 & NR & 35 & 351 & - & 15 & 2 & 308 & - & 20 & 730 \\
\hline Diet (I) & 0.5 & NR & 60 & 367 & - & 30 & 2 & 215 & - & 17 & 690 \\
\hline
\end{tabular}

${ }^{*}$ Total quantity in terms of total number of bottles and/or cans sold; NR indicates where no sales figures were provided. tTotal figures have been rounded off to the nearest 10 .

\section{Coca Cola}

In Delhi, the price that the manufacturers charged retailers was less for $330 \mathrm{ml}$ cans of regular than for diet Coca Cola. With a manufacturing price of 20 INR for a $330 \mathrm{ml}$ can of regular Coca Cola, retailers were making a profit of 7 INR (28\%), while for the diet version, the profit made was only 2.5 INR (10\%). Similarly, the retail profit made by selling $600 \mathrm{ml}$ bottles of regular Coca Cola was $3 \cdot 5$ INR (16\%) compared with 0.5 INR $(0 \cdot 2 \%)$ from selling the diet version. In London, there was no difference in the price of regular and diet Coca Cola (Table 2).

In general, Coca Cola products were more expensive than their Pepsi counterparts in Delhi, whereas in London the reverse was observed (Table 2).

\section{Sales}

To ascertain the average daily sales of regular and diet products, we asked the store vendors or staff in drinking and/or eating establishments to provide us with the previous day's sales figures. Of the outlets that sold these products, fifty-two of $141(36 \%)$ were unable to provide us with accurate sales figures and only two were able to give us this information from their computerized stock database (one supermarket in Delhi and one in London). The remaining outlets estimated their sales figures.

In Delhi, the sale of regular Pepsi per day amounted to 22601, while that of diet Pepsi was 901 - only $4 \%$ of all Pepsi sold (Table 3). Similarly, the daily sales of regular
Coca Cola was 14201, while that for diet Coca Cola was only $801-6 \%$ of all Coca Cola sold (Table 4). Sales of regular products were substantially greater than those of diet products $(P<0 \cdot 0001)$. In London, for Pepsi, 2001 of regular product were sold and 901 of diet Pepsi $-45 \%$ of all Pepsi sold $(P<0 \cdot 0001 ;$ Table 3$)$. For Coca Cola, the difference was less marked with 7301 sold of regular and 6901 of diet Coca Cola, 94\% of all Coca Cola sold (Table 4).

\section{Discussion}

Our hypothesis that diet Pepsi and Coca Cola were equally available in both Delhi and London was not supported by our findings. Diet Pepsi and Coca Cola were much less available in Delhi than London, but regular versions were equally available. Furthermore, availability of diet Pepsi and Coca Cola was greatest in the more affluent areas in Delhi, which was also found to be the case in London. Our hypothesis that there were no price differences between diet and regular Pepsi and Coca Cola was partly supported as we found little price difference between the most popularly sold colas in Delhi (Pepsi) and those sold in London (Coca Cola). However, retailers in Delhi were able to make more profit from selling regular than diet Coca Cola and diet Pepsi. Our hypothesis that sales of diet and regular Pepsi and Coca Cola would be similar was not supported in Delhi where we 
found that the sales of diet compared to regular Pepsi and Coca Cola were lower.

We found that Pepsi was much more widely available than Coca Cola in India, which may be explained by the following: PepsiCo, unlike Coca Cola, started marketing its products as a subsidiary of Punjab Agro Industrial Corporation in the mid-1980s, and it thus gained a 10-year lead over Coca Cola ${ }^{(14)}$. When trade and economic policies were relaxed in the Indian economy, Coca Cola approached the market selling an American way of life, which failed to resonate among the Indian population. By 2001, Coca Cola focused its attention on competitive pricing compared with traditional Indian soft drinks (e.g. green coconut water, freshly squeezed fruit and vegetable juices, lassi) and introduced a smaller bottle of $200 \mathrm{ml}$ (priced $50 \%$ of the standard container) at a price of 5 INR. It also doubled its distribution to retail outlets from $13 \%$ in 2001 to $25 \%$ in $2003^{(14)}$.

There are limitations to the present study. We covered central areas of two large cities in India and the UK. The data collected may not be representative of other cities and cannot give useful information on rural areas where $70 \%$ of the Indian population lives ${ }^{(16)}$. Sales figures relied on the estimated quantities sold and as such may not be accurate, although the differences reported between the sales of diet and regular products in India were very large and unlikely to be explained by measurement error. In addition, we were unable to ascertain the price at which regular and diet Pepsi and Coca Cola were sold by manufacturers to the wholesalers (distributers). Although the manufacturers' list suggests retail prices for their products, they are not mandatory and it is unclear whether the prices are influenced by the wholesalers in India. We also did not collect data on the sale of healthier alternative and substitute drinks such as water and freshly squeezed fruit juices. Bottled water is widely available in retail outlets in Delhi; the MRP cost of a litre of which is 13 INR, much below the prices for regular and diet Pepsi and Coca Cola. Freshly squeezed fruit juices (the prices vary according to the type of fruit and quantity) are available at specific stores which we did not visit since they did not stock carbonated drinks. Future studies might look at alternatives, comparative prices and consumer preferences.

Despite these limitations, it is clear that the availability of diet products is limited and there may be less profit in selling them, both of which act as barriers to customer choice and tend to increase unnecessary intake of 'hidden' energy. If all the shops selling regular Pepsi and Coca Cola were to sell the dietary versions as well, and if the financial disincentives for both vendors and customers for diet products were reduced, it is likely that demand for the lower-energy option would rise to the levels seen in those outlets selling both types of the product - about a threefold higher consumption. Marketing strategies in India do not appear to favour the promotion of diet drinks. Expenditure on marketing amounts to $10 \%$ of Coca Cola's and $6 \%$ of PepsiCo's total profits ${ }^{(20)}$ and heavily targets young people, adopting stealth strategies (promote 'safer' so-called healthier versions of products to increase its sales) and using product placement in films and television and celebrities such as Britney Spears and Shah Rukh Khan to endorse products ${ }^{(13,21-23)}$.

The implications of the promotion of Pepsi and Coca Cola are significant for India, which is already experiencing an obesity epidemic ${ }^{(24)}$. One can of regular Pepsi contains $573 \mathrm{~kJ}$ (137 kcal). Consumption of one can per day above the required daily need of $7845 \mathrm{~kJ}$ ( $1875 \mathrm{kcal})$ for an average woman for a year equates to a weight gain of $6.5 \mathrm{~kg} /$ year. To mitigate the intake of $573 \mathrm{~kJ}$ ( $137 \mathrm{kcal})$, a person weighing $60 \mathrm{~kg}$ would need to jog for $20 \mathrm{~min} / \mathrm{d}$ or walk for $45 \mathrm{~min} / \mathrm{d}^{(25-27)}$. Moreover, sugar-sweetened soft drinks increase hunger, decrease satiety and calibrate taste preference to a high level of sweetness that generalizes to other high-energy foods ${ }^{(7,27-29)}$.

In India, as in most developing countries, growing affluence has spurred the demand for clean and safe drinking water and the increased demand for bottled water has further boosted total soft drink sales ${ }^{(15)}$. In 2006, the Indian Migration Study determined that the rate of consumption of at least one aerated drink per week (Fanta/ Pepsi/Coca Cola) was 19\% among those under 30 years of age compared to $8 \%$ among those more than 51 years ${ }^{(30)}$. A study on the knowledge of nutrition of adolescent girls in Hyderabad in 2007 found that 50\% consumed an aerated drink 1-2 times/week irrespective of socio-economic status ${ }^{(31,32)}$. Soft drinks were once considered products only for the affluent, but by 2003, the sales of carbonated drinks were equally distributed across socio-economic groups in India ${ }^{(14)}$, which concurs with our finding that a majority of outlets in the poorest areas of Delhi sold regular Pepsi or Coca Cola.

Trends in consumption of carbonated beverages in USA and Europe are on the decline, prompting the Chief Executive Officer of PepsiCo to emphasize the importance of emerging markets in developing countries ${ }^{(33)}$. The declining trend in the developed world has occurred in countries with differing nutritional policies and health promotion programmes ${ }^{(34,35)}$. It seems likely that the trend has been driven by growing consumer concern about multinational corporate activities ${ }^{(36)}$, consumer demand for drinks that are perceived to be healthy ${ }^{(37)}$ and the massive growth in the bottled water market ${ }^{(15)}$. Against this background of stronger promotion of carbonated drinks in developing countries, it is essential that policy makers are aware of the potential nutritional consequences of uncontrolled advertising of carbonated beverages on children, the use of product placement in mass media and the penetration of carbonated beveragevending machines in schools ${ }^{(38-39)}$.

The costs of both Pepsi and Coca Cola in India are high relative to average incomes in India and the $\mathrm{UK}$, but this does not seem to act as a substantial barrier for purchase 
and consumption. There is limited research on the influence of taxes and subsidies on nutritional quality of food purchases. Evidence suggests stronger support for taxes than for subsidies as a means of reducing consumption of less healthy foods ${ }^{(40)}$. It has been estimated that a $10 \%$ increase in soft drink prices would reduce consumption by $8-10 \%{ }^{(43)}$. However, the implementation of such a policy would require political will. Recent attempts by the US Senate panel, which proposed a tax on sugar-sweetened drinks to fund a 'Health Care overhaul', were quashed following heavy lobbying by the US beverage industry ${ }^{(42,43)}$. This is despite current evidence suggesting that taxing carbonated drinks is associated with a reduction in consumption among overweight and obese children who come from low-income families and ethnic minority groups ${ }^{(44)}$.

Public health initiatives such as nutritional education programmes may be another way of tackling the rising rates of consumption of carbonated high-energy drinks in India. However, both the communication of food risk and changing individual behaviour are complex, difficult and often unsuccessful in the long term ${ }^{(45)}$. For example, major gaps exist in health and nutrition-related knowledge and health behaviour of urban children, parents and teachers in northern India ${ }^{(46)}$. Supporting these findings, a recent study in northern India showed that, in the short term, an urban school-based multi-component nutrition and lifestyle intervention reduced the consumption of carbonated drinks and other energy-dense foods and, most importantly, had a beneficial effect on the obesity and metabolic risk profile ${ }^{(47)}$.

\section{Conclusion}

If current consumption patterns of regular Pepsi and Coca Cola continue unchecked, they may make a substantial contribution to the growing obesity and diabetes epidemics in India. Low availability of diet versions of Pepsi and Coca Cola in less affluent areas of Delhi is likely to exacerbate obesity and diabetes trends. Price differentials to promote diet versions and other healthier or traditional low-energy drinks may be beneficial.

\section{Acknowledgements}

The present study was funded by the South Asia Network for Chronic Disease. The authors have no conflict of interest to declare. F.C.T. and S.E. contributed to the original concept and prepared the manuscript; F.C.T., A.S., S.K. and G.S. collected the data; A.S. and F.C.T. conducted the data analysis. All authors approved the manuscript.

\section{References}

1. Popkin B (2006) Global nutrition dynamics: the world is shifting rapidly toward a diet linked with noncommunicable diseases. Am J Clin Nutr 84, 289-298.
2. Drewnowski A (2004) Obesity and the food environment. Am J Prev Med 27, Suppl. 3, 154-162.

3. Burns C, Sacks G \& Gold L (2008) Longitudinal study of consumer price index trends in core and non-core foods in Australia. Aust N Z J Public Health 5, 450-453.

4. Cummings S \& McIntyre S (2006) Food environments and obesity - neighborhood or nation. Int J Epidemiol 35, 100-104.

5. Blouin C, Chapra M \& Van Der Hoeven R (2009) Trade and social determinants of health. Lancet 373, 502-505.

6. Wild S, Roglic G, Green A et al. (2004) Global prevalence of diabetes. Diabetes Care 27, 1047-1053.

7. Harrington S (2008) The role of sugar-sweetened beverage consumption in adolescent obesity: a review of the literature. J School Nurs 24, 3-12.

8. Forshee R, Anderson PA \& Storey ML (2008) Sugarsweetened beverages and body mass index in children and adolescents: a meta-analysis. Am J Clin Nutr 87, $1662-1671$.

9. Vartanian L, Schwartz M \& Brownell K (2007) Effects of soft drink consumption on nutrition and health: a systematic review. Am J Public Health 97, 669-675.

10. Schulze M, Manson JE \& Ludwig DS (2004) Sugarsweetened beverages, weight gain, and incidence of type 2 diabetes in young and middle aged women. JAMA 292, 927-932.

11. Anon. (2009) Soft drinks and obesity - global threats to diet and health. http://www.dumpsoda.org/health (accessed April 2009).

12. Bolling C (2002) Globalisation of the Soft Drink Industry. Briefing Paper. Washington, DC: US Department of Agriculture, Economic Research Service.

13. Nelson C (2009) PepsiCo to invest $\$ 500$ million into India. http://www.indusbusinessjournal.com (accessed May 2009).

14. Kaye J (2004) Coca Cola India. Report Under the Direction of Professor Argenti. Hanover, NH: Tuck Business School at Dartmouth.

15. Regmi A (2008) Global Food Markets: International Consumer and Retail Trends. Briefing Paper. Washington, DC: US Department of Agriculture, Economic Research Service.

16. Government of India (2006) Census of India 2001. http:// www.censusindia.gov.in (accessed May 2009).

17. Office for National Statistics (2004) http://www.ons.gov.uk/ population/neighbourhoods (accessed May 2009).

18. STATA Corp. (2007) STATA Windows Version 10. TX, USA: STATA Corp.

19. Coinmill.com (2009) The currency converter. http://www. coinmill.com (accessed March 2009).

20. Lang T, Rayner G \& Kaeling E (2006) Report on The Food Industry, Diet, Physical Activity and Health. London: Centre for Food Policy, City University.

21. Anon. (2009) Myths and morality at Coca Cola (Editorial). Lancet 373, 1224.

22. Brownell K \& Warner K (2009) The perils of ignoring history: big tobacco played dirty tricks and millions died. How similar is food? Milbank $Q \mathbf{8 7}, 259-294$.

23. Seshan G (2008) Soft drink makers change ad strategy. Business News India, 25 March.

24. Reddy S, Shah B, Varghese C et al. (2005) Responding to the threat of chronic disease in India. Lancet 366, 1744-1749.

25. Pepsico (2009) Nutrient and ingredient information for carbonated drinks. http://www.pepsi.com/productinfo (accessed April 2009).

26. Hill J, Wyatt H, Reed G et al. (2003) Obesity and environment: where do we go from here? Science 299, 853-855.

27. Ainsworth B, Haskell W \& White M (2000) Compendium of physical activities: an update of activity codes and MET intensities. Med Sci Sports Exerc 32, Suppl. 9, S498-S504. 
28. Vartanian L, Drewnowski A \& Bellisle F (2007) Liquid calories, sugar and body weight. Am J Nutr 85, 651-656.

29. Ebbeling C, Feldman HA, Osganian SK et al. (2006) Effects of decreasing sugar sweetened beverage consumption on body weight in adolescents: a randomized, controlled pilot study. Pediatr 117, 673-680.

30. Lyngdoh T, Kinra S, Ben Shlomo Y et al. (2006) Sibrecruitment for studying migration and its impact on obesity and diabetes. Emerg Themes Epidemiol 3, 2.

31. Rao D, Vijayapushpam T, Subba Rao G et al. (2007) Dietary habits and effects of two different educational tools on nutrition knowledge of school going adolescent girls in Hyderabad, India. Eur J Clin Nutr 61, 1081-1085.

32. Vijayanpushpam T, Menon K, Rao D et al. (2003) A qualitative assessment of nutrition knowledge levels and dietary intake of schoolchildren in Hyderabad. Public Health Nutr 6, 683-688.

33. Geller M (2010) Pepsi eyes emerging markets, health fare Reuters US Edition. http://www.reuters.com

34. Park H (2008) Nutrition policy in South Korea. Asia Pac J Clin Nutr 17, Suppl. 1, 343-345.

35. Nakamura $\mathrm{T}$ (2008) The integration of school nutrition program into health promotion and prevention of lifestylerelated diseases in Japan. Asia Pac J Clin Nutr 17, Suppl. 1, 352-356.

36. Organisation for Economic Co-operation and Development (2008) Guidelines for Multinational Enterprises. Paris: OECD.

37. Drinks Business Review (2009) Carbonated beverages producers must react to declining sales. http://www. softdrinks.drinks-business.com (accessed May 2010).

38. Johnson-Taylor W \& Everhart J (2006) Modifiable environmental and behavioral determinants of overweight among children and adolescents: report of a workshop. Obes Res 14, 929-966.
39. Matson-Koffman DM, Brownstein JN, Neiner JA et al. (2005) A site-specific literature review of policy and environmental interventions that promote physical activity and nutrition for cardiovascular health: what works? $\mathrm{Am} \mathrm{J}$ Health Promot 19, 167-193.

40. Epstein L, Dearing K, Roba L et al. (2010) The influence of taxes and subsidies on energy purchased in an experimental purchasing study. Psychol Sci (Epublication ahead of print version)

41. Andreyeva T, Long MW \& Brownell KD (2010) The impact of food prices on consumption: a systematic review of research on the price elasticity of demand for food. $\mathrm{Am} \mathrm{J}$ Public Health 100, 216-222.

42. Wayne A (2009) Senate panel suggests tax on sweet drinks to pay for health care overhaul. Briefing document. Washington Health Policy Week in Review, 26 May.

43. Scott-Thomas C (2010) Nationwide soda tax proposal fizzles out. http://www.foodnavigator-usa.com/Legislation/ 9/2/2010 (accessed May 2010).

44. Sturm R, Powell L, Chriqui J et al. (2010) Soda taxes, soft drink consumption, and children's body mass index. Health Aff (Millwood) 29, 1052-1058.

45. McGloin A, Delaney L, Hudson E et al. (2009) Nutrition communication. The challenge of effective food risk communication. Proc Nutr Soc 68, 135-141.

46. Shah P, Misra A, Gupta N et al. (2010) Improvement in nutrition-related knowledge and behaviour of urban Asian Indian school children: findings from the 'Medical education for children/Adolescents for Realistic prevention of obesity and diabetes and for healthy ageing' (MARG) intervention study. Br J Nutr 7, 1-10.

47. Singhal N, Misra A, Shah P et al. (2010) Effects of controlled school-based multi-component model of nutrition and lifestyle interventions on behavior modification, anthropometry and metabolic risk profile of urban Asian Indian adolescents in North India. Eur J Clin Nutr 64, 364-373. 
Appendix

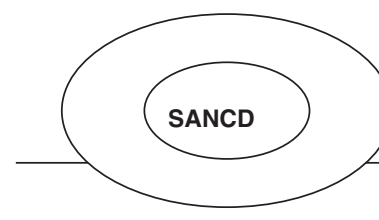

SOUTH ASIA NETWORK CHRONIC DISEASE

Diet Pepsi/Coca Cola questionnaire

ID

This short questionnaire aims to find out the availability diet and non diet coke/pepsi in food and/or drink for outlets in specific areas of Delhi. We need to know the availability, unit price, package size of these drinks and average sale in one day's trading

\begin{tabular}{|l|l|l|l|}
\hline 1 & Day and date of interview & \multicolumn{2}{|l|}{} \\
\hline 2 & Area & \multicolumn{2}{|l|}{} \\
\hline 3 & Name and type of outlet & $\square$ No \\
\hline 4 & Do you sell Pepsi or Coca Cola? & $\square$ Yes & $\square$ No \\
\hline 5 & Willing to participate? & $\square$ Yes & \\
\hline 6 & Respondent's name and capacity at work \\
\hline
\end{tabular}

Notes:
\begin{tabular}{|l|l|l|l|l|l|l|l|l|l|l|l|l|l|}
\hline $\begin{array}{l}\text { Pepsi } \\
\text { Stock size in } \mathrm{ml}\end{array}$ & 200 & 300 small & 330 & 400 med & 500 large & 600 & 1000 & 1500 & 2000 & 2250 & other \\
\hline $\begin{array}{l}\text { Enter price INR } \\
\text { normal } \\
\text { cold }\end{array}$ & & & & & & & & & & & \\
\hline $\begin{array}{l}\text { Enter number } \\
\text { sold yesterday }\end{array}$ & & & & & & & & & & & & & \\
\hline \begin{tabular}{|l|l|l|l|l|l|l|l|l|l|l|l|} 
Diet Pepsi stock in \\
ml
\end{tabular} & 200 & 300 small & 330 & 400 med & 500 large & 600 & 1000 & 1500 & 2000 & 2250 & other \\
\hline $\begin{array}{l}\text { Enter price INR } \\
\text { normal } \\
\text { cold }\end{array}$ & & & & & & & & & & & \\
\hline $\begin{array}{l}\text { Enter number sold } \\
\text { yesterday }\end{array}$ & & & & & & & & & & & & & \\
\hline
\end{tabular}

Notes:

\begin{tabular}{|l|l|l|l|l|l|l|l|l|l|l|l|}
\hline $\begin{array}{l}\text { Coke stock in } \\
\text { ml }\end{array}$ & 200 & 300 small & 330 & 400 med & 500 large & 600 & 1000 & 1500 & 2000 & 2250 & other \\
\hline $\begin{array}{l}\text { Enter price INR } \\
\text { normal } \\
\text { cold }\end{array}$ & & & & & & & & & & \\
\hline
\end{tabular}

\begin{tabular}{|l|l|l|l|l|l|l|l|l|l|l|l|}
\hline $\begin{array}{l}\text { Diet Coke } \\
\text { stock size in ml }\end{array}$ & 200 & 300 small & 330 & 400 med & 500 large & 600 & 1000 & 1500 & 2000 & 2250 & other \\
\hline $\begin{array}{l}\text { Enter price INR } \\
\text { normal } \\
\text { cold }\end{array}$ & & & & & & & & & & \\
\hline & & & & & & & & & & \\
\hline $\begin{array}{l}\text { Enter number } \\
\text { sold yesterday }\end{array}$ & & & & & & & & & & & \\
\hline
\end{tabular}

Notes:

QUESTIONS: (if willing to provide)

Reasons for stocking or NOT stocking regular Pepsi or Coca Cola 